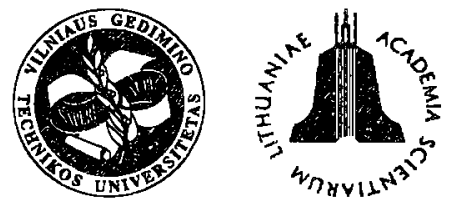

ISSN 1648-4142 TRANSPORT

http:/www.vtu.lt/english/editions

\title{
THE ANALYSIS OF POSSIBILITIES TO ENTER THE PORTS OF THE BALTIC SEA FOR BIG CONTAINER SHIPS
}

\author{
Vytautas Paulauskas, Donatas Paulauskas, Birutė Plačienė \\ Klaipèda University (KU), Bijūnu 17, LT-5800 Klaipèda, Lithuania. E-mail: laivyba@jtf.ku.lt
}

Received 200202 07; accepted 20020304

\begin{abstract}
The article investigates technical, economical and organizational possibilities to enter the Baltic ports for container ships as the result of economic globalization and the increase of transcontinental container transportation.
\end{abstract}

Keywords: containers, container ships, ship entry in to ports conditions.

\section{Introduction}

The transportation of packed cargoes is very important in such case when valuable and sensitive goods are transportated. So, in case of optimizing the elements of production chain, the processing of raw materials and the production of some parts are moved close to the places where raw materials are got. Although products assembling places are concentrated where there is high technological culture, the transportation of spare parts and final production gets a greater attention [1, 2].

In case when spare parts and final high quality production are valuable and have to be well attended the transportation under such conditions can be done only if the goods are packed [3-5].

So container and inter modal transportation is very important and has great future [3-7]. The transportation of containers in the Baltic Sea and the whole world is changing $[3,5,6,8]$, that is why it is important to react quickly and to prepare for it. The analysis of container cargo flow is based on the theory of transport $[1,2,7,9$, 10], which permits us to prepare port infrastructure and organizational tools in advance, so that we could take more from the change of transportation markets.

\section{Tendencies of Container Transportation}

Containers started to be transported during the war in Korea, later the first container shipping line between New-York and Puerto-Rico (1956), was created in the USA and during recent 15 years container transportation by sea increases up to $8-12 \%$ every year. Now about 600 million of containers per year are transported and more than $1 / 3$ of them, that is about 220 million of containers in TEU units (20 feet container) per year are transported by ships and the transcontinental container transportation increases now $[3,6,5]$.
The increase of containers quantity for one ship decreases the transportation cost. Now the transportation cost for one container from Singapore to Rotterdam by a container ship of the capacity of $6000 \mathrm{TEU}$, including terminal cost, is about $700-750$ US dollars per one TEU. Terminal cost is about $120-200$ US dollars per TEU and without terminal cost the freight is just $350-400$ US dollars per TEU [6].

Now the biggest container ships which work on container shipping lines have the capacity of $7000 \mathrm{TEU}$ and there are more than 20 units of such type of ships nowadays and about 100 container ships have the capacity of about 6000 TEU.

China has odered and now container carriers with the capacity of $9180 \mathrm{TEU}$ are under construction, and also container carriers with the capacity of 12500 TEU are designed and container carriers with the capacity of more than 14000 TEU have been designed.

The parameters of $12500 \mathrm{TEU}$ capacity container ship are: $400 \mathrm{~m}$ of length, $57 \mathrm{~m}$ of width, $15,5 \mathrm{~m}$. of draft. Special terminals for such and bigger container ships are designed. At present about 10 special container terminals for the container ships with the capacity of 12500 TEU and more are under design and construction in South East Asia. There about $50 \%$ of containers are transported, also 5 such terminals are designed and are under construction, in the USA - 3 terminals and in Western Europe - 3 terminals.

Besides the mentioned POSTPANAMAX type container ships at present in the world there are more than 7000 special container ships and more than 1500 ships which work on transcontinental container shipping lines have the capacity from $2500 \mathrm{TEU}$ to $4000 \mathrm{TEU}$. The main dimensions of these container ships are: length up to 180 $-220 \mathrm{~m}$; width up to $22-28 \mathrm{~m}$; draft up to $8,5-11,5 \mathrm{~m}$ (full capacity). Mainly container ships carry up to $40 \%$ of empty containers and use about $60-80 \%$ of the weight capac- 
ity, it means that in many cases draft of the mentioned container ships is about $8,0-9,0 \mathrm{~m}$.

\section{Inter Modal and Sea Container Transportation}

The study of the sea container transportation should be made together with inter modal transportation, i. e. transport units such as lorries, trailers, road trailers, wagons and other. Inter modal transportations are of a special transportation type because in many cases this method of transportation can arrange transportation from door to door without additional loading operations. It is very important, especially in one continent, where there are good roads, railways and the network of Ro-Ro shipping lines. The mentioned advantages of inter modal transportation "push out" container transportation in one continent. For example in the USA, Western and Central Europe and some other places the biggest part of goods in one region is transported by inter modal transport and the main reason is big taxes of container terminals and the possibility to deliver goods to destination places very fast by inter modal transport. In the past regulations were used, that on the distance up to $1000 \mathrm{~km}$ it is necessary to use road transport (of course, if there is a good road network), on the distances up to $1500-2000 \mathrm{~km}$ - railway transport and on bigger distances water transport should be used. Ai present these regulations are not valid and road transportation distances increased, especially in regions where there are good roads and Ro-Ro shipping line network. Now inter modal transportations, on the basis of road transportation are reasonable on the distances up to 2000 $-2500 \mathrm{~km}[5,6]$.

A new inter modal transportation situation partly changed the container transportation because container transportations are more expensive (mainly due to terminal costs), take more time because it is necessary to spend some time for loading operations and it requires several handlings during transportation.

At the same time inter modal transportation can not be used in transcontinental transportation especially between three main regions of industrial concentration, that is between South East Asia (including Japan), the USA together with Canada and Mexico (actually North America) and Western Europe.

Economic globalization incorporates more and more countries into production chains and as a result the Baltic Sea countries as well as the mentioned triangle: South East Asia, North America, Europe become members of their production chains. On the basis of this activity real new possibilities to increase transcontinental container transportation via the Baltic Sea ports are created.

At the same time there is a tendency of container transportation decrease in West, Central and North Europe and big increase of the inter modal, especially road transportation. In recent years the container flow into and from West European countries via East Baltic ports de- creased twice and transcontinental container flow has increased more than two times.

\section{Possible Contaher Varket in the Batic Sea Bagign}

In 2001 via the Baltic Sea ports about 3,2 million of TEU were transported. Container distribution via the Baltic Sea countries is shown in Table 1.

Distribution of container handing in the Baltic Sea ports is shown in Table 2.

The container transportation via the Baltic Sea ports from a geographical point of view has changed very much in recent years. It mears the decreased number of containers which were delivered to or from European countries and the increased number of containers which were carried to the USA, Canada, South East Asia and from these regions $[3,5,6]$.

In this case container market in the Baltic Sea region can be evaluated on the basis of co-operation links between the continents and on the basis of existing situation in Europe and especially in the Baltic Sea region. In the evaluation of existing tendencies, that a part of goods will be carried in the European continent and transcontinental links, it is more useful to make the analysis of the whole container flow separately:

- container flow in European region;

Table 1. Container distribution in the Baltic Sea countries ports in 2000

\begin{tabular}{|l|c|}
\hline \multicolumn{1}{|c|}{ Country } & Portion, $\%_{2} \%$ \\
\hline Finland & 30,0 \\
\hline Sweden & 28,4 \\
\hline Poland & 9,3 \\
\hline Russia & 9,3 \\
\hline Denmark & 7,3 \\
\hline Latvia & 4,8 \\
\hline Germany (Baltic Sea ports) & 4,6 \\
\hline Estonia & 4,4 \\
\hline Lithuania & 1,9 \\
\hline
\end{tabular}

Table 2. Container distrubution in the Baltic ports in 2000

\begin{tabular}{|l|c|}
\hline \multicolumn{1}{|c|}{ Port } & $\begin{array}{c}\text { Handling TEU in 2009 } \\
\text { (fhousands) }\end{array}$ \\
\hline Geteborg & 583 \\
\hline Helsinki & 346 \\
\hline Gdynia & 215 \\
\hline St-Peterburg & 205 \\
\hline Copenhagen & 175 \\
\hline Kotka & 165 \\
\hline Hamina & 115 \\
\hline Liubek & 95 \\
\hline Riga & 85 \\
\hline Helsinborg & 75 \\
\hline Klaipeda & 40 \\
\hline
\end{tabular}


- container flow in transcontinental transportation.

For the evaluation of container flow typical forecast systems can be used, which at first calculate flow tendencies and calculate errors of the forecast flows, taking as a basis that flow distribution corresponds to the Gauss law $[1,9,10]$.

In this case for the calculation of flow tendencies liner forecasting methods can be used, on the basis of clear prehistory. In such cases for the flow tendency calculation this formula can be used:

$$
Q_{\theta}=Q_{\theta=0}+b \theta
$$

where: $Q_{\theta=o}-$ flow at the begining of prehistory; $b$-coefficient which is calculated as:

$$
b_{i}=\frac{Q_{i}-Q_{\theta=O}}{Q_{i}}
$$

$\theta$ - the period of time from the beginning of prehistory, and finally would be:

$$
b=\frac{\sum b_{i}}{\theta} .
$$

Forecasting error for the calculation period can be calculated as:

$$
e^{2}=M\left(\theta_{\theta}-\theta_{\theta}\right)=\delta_{y}^{2},
$$

where $\delta_{y}$-dispersion which can be calculated as:

$$
\delta_{y}=\frac{1}{n-1} \sum\left(Q_{i}-m_{y}\right)
$$

where $m_{y}$ - mathematical expectation which can be calculated as follows:

$$
m_{y}=\frac{1}{n} \Sigma Q_{i}
$$

where: $Q_{i}$ - the result of prehistory every period, for example years; $n$ - the number of prehistory years.

If we take into account that container transportation inside Europe (European Countries goods transported among European Countries are handled in ports by Lo-Lo (vertical) method the last several years is constant, but the total container transportation tendency in the world is increasing, it is possible to state that container transportation is increasing on the basis of transcontinental transportations. Graphically general dependences can be shown in Fig 1.

On the basis of the world container transportation statistics from 1986 till 2001 (Table 3) it is possible to receive mathematical dependences for all container flows for the next few years. be:

For the calculation in relative data the formula (1) will

$$
Q_{\theta}=Q_{\theta=0}+b \theta \text {, }
$$

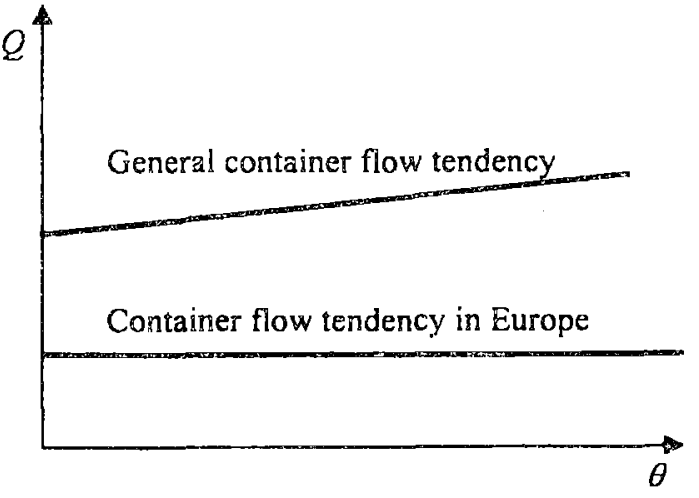

Fig 1. Fragment of the container transportation

where $Q_{\theta=0}$ can be taken as a zero, in this case the last formula can be:

$$
Q_{\theta}=b \theta \text {. }
$$

In this case on the basis of the data from Table 3 it is possible to calculate coefficient $b$ and it is possible to calculate container flows for the forecast period.

In case of regular increasing tendency of transcontinental containers, on the basis of statistical data of the last some years (after 1998 Russia crisis), because for this period the real situation can be received, according to which the real mathematical dependency can be found which permits to calculate transcontinental container flows after a few years (Fig 2).

Forecast error can be calculated using the methods shown above. On the basis of forecast error $e$ optimistic and pessimistic scenarios can be calculated and oprimistic period (a') or pessimistic period (b') can be calculated too.

Table 3. Conteiner transportation by sea in $1986-2000$

\begin{tabular}{|c|c|}
\hline Year & $\begin{array}{c}\text { Number of containers, mil. } \\
\text { TEU }\end{array}$ \\
\hline 1986 & 62 \\
\hline 1987 & 68 \\
\hline 1988 & 76 \\
\hline 1989 & 82 \\
\hline 1990 & 88 \\
\hline 1991 & 96 \\
\hline 1992 & 106 \\
\hline 1993 & 116 \\
\hline 1994 & 130 \\
\hline 1995 & 144 \\
\hline 1996 & 156 \\
\hline 1997 & 172 \\
\hline 1998 & 184 \\
\hline 1999 & 195 \\
\hline 2000 & 212 \\
\hline 2001 & 225 (preliminary data) \\
\hline
\end{tabular}




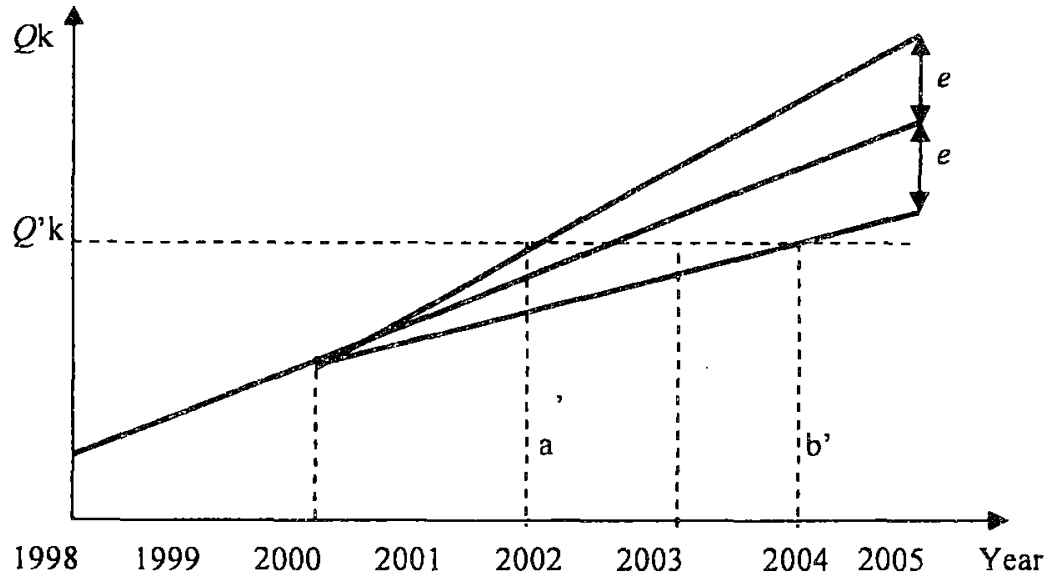

Fig 2. Forecast of container flows for the next years

6. Economical Conditions for Big Container Ships entry in the Baltic Sea Ports

As it was mentioned before, about 3,2 million of TEU per year (preliminary data of 2001) are transported via all the Baltic Sea ports. The container flows have grown up about $15 \%$ per year and about $40-45 \%$ of them are transcontinental containers. In this case all the quantity of the transcontinental container flows is from 1000000 up to $1400000 \mathrm{TEU}$ per year. After 3 years it is possible to make prognoses for about $1500000-1800000$ TEU transcontinental containers per year.

The East Baltic ports mainly serve hinterland which extends from the East

On the basis of evaluation that about $30 \%$ of containers transported via the East Baltic ports were transcontinental containers, it is possible that 650000 TEU which were handled in the East Baltic ports in 2000, about 200000 TEU were transcontinental containers (according to preliminary data in 2001 the portion of the transcontinental containers in the East Baltic ports was about $40-$ $45 \%$ ) and the average container number increased about $15 \%$. On the basis of this data and tendencies it is possible to forecast that after 3 years, i. e. in 2003, the total number of containers handled in the East Baltic ports will be about 850000 TEU and more than 350000 TEU will be transcontinental containers.

\section{The Possibilities of Baltic Ports Regarding Transcon- tinental Container Ships}

In case of relatively small container flows it is necessary to orientate towards the relatively small container ships. It is necessary to take into account that at present more than 1000 container ships which work on transcontinental container lines have the capacity from 2500 up to 3000 TEU and the dimensions of such ships are: length about $210 \mathrm{~m}$, width about $26 \mathrm{~m}$, draft from 9,0 up to $10,5 \mathrm{~m}$ [8]. It is possible to expect that such types of ships are able to visit the East Baltic ports.

Many Baltic Sea ports have containet terminals or they can use other terminals for the container handling tasks near which container ships of 3-4 generations with the capacity up to 3000-3500 TEU can be moored. Such ports can be named: Klaipeda, Ventspils, Gdynia, Riga, Tallinn, St.-Petersburg, Geieborg and others.

It is necessary to take into account that a big part of the containers about $65 \%$ of total containers from 3,2 million of TEU handled in the Baltic Sea ports in 2001 is transported via the mentioned ports. The number of transcontinental containers today in these ports is more than 500000 TEU per year.
Baltic Sea coast to Ural, including North Ukraine and partly Middle Asia countries and the number of transcontinental containers in the mentioned ports in 2003 could be about $450000-500000$ TEU.

In case if container ship uses more than $70 \%$ of its capacity normally it is economically reasonable and the loading in one port of about $200-400$ containers, that is about $10 \%$ of the ship capacity is considered an economically reasonable entry into a port. In this case, if a container ship with the capacity of $3000 \mathrm{TEU}$ is taken as a basis, such ship must load and unload about 5000 containers (in one port at least 300 TEU) during the voyage in the Baltic Sea.

Economical analysis of the container ship is reasonable regarding a port, where a small quantity of containers is handled at the moment. Such situation is in the Klaipeda port, where in 200150000 TEU were handled and about 20000 TEU were transcontinental containers. Dividing this number of transcontinental containers per weeks in a year we get that in the Klaipeda port on the average every week about 400 TEU of transcontinental containers, were handled that is enough for one container ship per week.

Taking into account that in the East Baltic ports transcontinental container flows are about $5000 \mathrm{TEU}$ per week, now it is possible to supply fully at least one container ship of 3-4 generations per week.

At the same time transcontinental container liner ships sailing to the Baltic Sea ports will visit the main West European ports, where transcontinental containers will be partly loaded and a part of the containers will be carried by these ships from the main West European ports to the East Baltic Sea ports. The sailing of transcontinental container ships will be economically useful, if in the East Baltic ports on average about 2400 - 3200 TEU [7] will be handled and in every port as it was mentioned before about $200-300$ TEU will be handled. In such case only the East Baltic ports can supply the necessary quantity of coniainers at least two - three container ships of 3 -4 generations per week (from the economical point of view). 
All expenditures are paid by a customer and any additional loading and unloading in the main West European ports and later transportation by feeder ships to the East Baltic ports increase the transportation costs on the average $300-400$ US dollars per TEU, or, if calculated per tone, - about $15-30$ US dollars per one tone of cargo.

The decrease of transportation costs can help to increase export goods competition and importing goods it can help to increase goods turnover and this situation can increase economics growth of the regions and countries. The problems of goods transportation costs and delivery time optimization can be solved on the basis of transcontinental container transportation directly to the East Baltic or other Baltic ports.

\section{Actions to Be Taken in the East Baitic Ports Atracting Transcontinental Container Lines to the East Baltic Ports}

The attraction of transcontinental container shipping lines to the Baltic ports is possible only on the basis of joining the activities of the interested ports, because no one of the East Baltic ports at this moment is able (on the basis of existing transcontinental container quantity) to guarantee the minimum required container quantity for the container ship of $3-4$ generations.

In this case port co-operation actions can faster solve the problem of attracting transcontinental container shipping lines to the Baltic Sea and the actions necessary to realize this very important idea not only for the concrete companies, but for the regions, are the following:

- $\quad$ it is necessary to create conditions in ports, making minimum resistance for the entry of transcontinental container ships;

- $\quad$ it is necessary to agree to special port dues and stevedoring tariffs for transcontinental container ships that at the first stage with the minimum loading shipping lines incur not big losses;

- it is necessary to develop such marketing activity, that it would be possible to change the existing situation, that companies which prepare transcontinental containers in the East Baltic would not use the existing system, when goods are delivered to the main West European ports by trailers and loaded into transcontinental containers.

To solve the mentioned problems it is reasonable to prepare a joined project of the East Baltic or Baltic ports for the attraction of transcontinental container shipping lines to the Baltic Sea and to present this project to the operators of transcontinental container shipping lines and the main cargo owners, who use transcontinental container transportation and to provide marketing.

\section{Conclusions and Recommendations}

1. Container transportation by sea is increasing in the world up to $8-12 \%$ every year.
2. On one continent, especially in Europe, North America, where road and Ro-Ro shipping lines networks are good, container transportation is on one level (not increasing), because containers are moved out by inter modal transportation.

3. Taking into account the toral container transportation increase in the world and the changes in container transportation by inter modal transportation in one continent or region, container quantities are increasing, especially in Europe, and it is linked with the increase of transcontinental container transportation.

4. The Baltic Sea region is one of the more intensive developing region in Europe, where container transportation increases up to $15-20 \%$ per year and this region has good perspectives for the container transportation in future.

5. Many Baltic ports have possibilities to work or can easily prepare their ports for the work with container ships of 3-4 generations.

6. In the nearest future, containers for $3-4$ transcontinental container ships per week can be supplied only by the East Baltic ports and in this situation it is necessary to start preparing for such transportation.

7. For the preparation and attraction of transcontinental container ships into the East Baltic Sea ports it is necessary to co-operate, and it is very important, that in the nearest $10-12$ years the East Baltic ports will be come partners in this respect, but not competitors.

8. Transcontinental container lines in the East Baltic ports can help to activate economic development in the East Baltic ports.

\section{References}

1. Baublys A. Introduction to the transport system theory. Vilnius: Technika, 1997. $300 \mathrm{p}$ (in Lithuanian).

2. Paulauskas V. Ports development. Klaipeda University publish house, 2000. $280 \mathrm{p}$ (in Lithuanian).

3. Romanenko A. Role of the Baltic sea region in world container shipping. Transit, BI-INFO, Tallinn, 2001, p. 61-66.

4. Paulauskas V. Ports development and logistics. Klaipeda University publish house, 1998, $164 \mathrm{p}$ (in Lithuanian).

5. EU Energy and Transport in Figures. EU, Luxembourg, 2001. $195 \mathrm{p}$

6. Paulauskas V. Baltic ports in transcontinental Maritime transportation. Transit, BI-INFO, Tallinn, 2001, p 2 - 6.

7. Standardization of ships and inland Waterways for River/ Sea Navigation. Brussels, 1996. 250 p.

8. Recommendations of the Committee for Waterfront Structures and waterways, EAU 1996. EU, Emst and Sohn, Berlin, $2000.600 \mathrm{p}$

9. Blotcorne L., Labbe M., Sevard G. A Be-level model and Solution Algorithm for a freight Traffic-Setting Problem. Transportation Science, Vol 34, 2000, p 289-302.

10. Cheung R., Powel W. Models and Algorithms for Distribution problems with Uncertain Demands. Transportation Science, Vol 30, 196, p $43-59$. 